\title{
The Enzymes of Lecithin Biosynthesis in Human Newborn Lungs. III. Phosphorylcholine Glyceride Transferase
}

\author{
RichaRd D. ZAGHMAN ${ }^{\mid 38]}$ \\ With the Technical Assistance of Agnes Chung \\ Department of Pediatrics of the University of Wisconsin and the Perinatal Center at St. Mary's Hospital, \\ Madison, Wisconsin, USA
}

\begin{abstract}
Extract
Phosphorylcholine glyceride transferase (EC. 2.7.8.2), the enzyme responsible for the final step of lecithin biosynthesis via the cytidine diphosphorylcholine (CDP-choline) pathway, is active in human neonatal lung tissue. A crude homogenate enzyme preparation in phosphate buffer was made from lung samples obtained at autopsy. The synthesis of product was linearly dependent upon protein concentration and linear with time for $30 \mathrm{~min}$. The Michaelis constant for CDP-choline was $1.4 \times 10^{-5} \mathrm{M}$. Optimal activity was attained at $\mathrm{pH} 7.5-8.0$, at $35-39^{\circ}$, in the presence of $\mathrm{Mg}$. Whole homogenate was 20-50 times as active as supernatant. No effect of oxygen or cysteine could be demonstrated. Triton and calcium inhibited the enzyme. The difference in enzyme activity between premature infants $\left(3.53 \times 10^{-7} \mathrm{~mm}\right.$ lecithin $/ \mathrm{mg}$ protein $)$ and infants of longer $\left(>32\right.$ weeks) gestation periods $\left(1.76 \times 10^{-7} \mathrm{~mm}\right.$ lecithin $/ \mathrm{mg}$ protein $)$ is statistically significant at the $95 \%$ confidence limit.

\section{Speculation}

Phosphorylcholine glyceride transferase could play a significant role in the relation between lung lecithin biosynthesis and respiratory distress syndrome of the human neonate. Ciharacterization and study of the enzyme in human lung may lead to definition of its role as the possible regulator of pulmonary surfactant biosynthesis. There may be a relation between the level of enzyme activity and gestational age.
\end{abstract}

\section{Introduction}

The relation between lung surfactant and respiratory distress syndrome in the neonate has been well established $[1,3,8,10,13,15,24]$. Lecithin (phosphatidylcholine) is a major component of lung alveolar surfactant $[7,20,22,23]$. Lecithin biosynthesis in lung tissue of experimental animals occurs by at least two pathways. One mechanism is by the formation of phos- phorylcholine and its transfer from CDP-choline to $\mathrm{D}-\alpha, \beta$-diglyceride $[2,5,16,27]$ and the other is the trimethylation of phosphatidyl ethanolamine $[6,14$, $18]$.

Lecithin biosynthesis in human newborn lung is being investigated indirectly by assaying the enzyme activities of the pathways. The activities and properties of choline kinase, methionine-activating enzyme, and phosphatidyl methyltransferase have been re- 
ported [30, 31]. The present investigation confirms that phosphorylcholine glyceride transferase (EC. 2.7.8.2), the enzyme responsible for the final step of lecithin biosynthesis via the CDP-choline pathway, is present in human newborn lung tissue, and further defines some of the basic properties of the enzyme system.

\section{Materials and Methods}

\section{Materials}

Cytidine diphosphocholine-1, $2 \cdot{ }^{14} \mathrm{C}$, with a specific activity of $115.5 \mathrm{mCi} / \mathrm{mmol}$, was obtained from Tracerlab [32]. The isotope was stored at $-20^{\circ}$ and was used without further purification. Dipalmitin (1,2-dipalmitoyl glycerol) was obtained from Sigma Chemical Company [33].

\section{Enzyme Assay}

Lung tissue of human newborn infants who died from a variety of causes was used as the source of phosphorylcholine glyceride transferase. The right lung was used in all cases, with no attempt to sample specific lobes. Tissues were removed 1-10 hr after death and were frozen until used. Tissues which remained at morgue conditions $\left(4^{\circ}\right.$, in situ) retained $85-90 \%$ of their original activity over that period of time, and could then be frozen for periods of at least 30 days without further loss of activity.

A crude enzyme preparation was made by homogenizing lung with 3 volumes of sodium phosphate buffer $(0.067 \mathrm{~m}, \mathrm{pH} 7.4)$. The assay was similar to that described by Baldwin and Cornatzer [4]. Components of the reaction mixture were: Dipalmitin $(1.17 \mathrm{mmol})$ in Tris- $\mathrm{HCl}$ buffer $(0.2 \mathrm{mmol}), \mathrm{pH} 8.5$, containing $0.01 \%$ Triton X-100; cytidine diphosphorylcholine ${ }^{-14} \mathrm{C}$ 1, 2-chloride $(0.5 \mathrm{mmol})$; $\mathrm{MgCl}_{2}$ (5.6 $\left.\mathrm{mmol}\right)$, and tissue homogenate. The total volume was $1.8 \mathrm{ml}$. The reaction mixture was incubated $45 \mathrm{~min}$ at $37^{\circ}$. The reaction was stopped by adding $0.10 \mathrm{ml} 12 \mathrm{~N} \mathrm{HCl}$. Water $(1.5 \mathrm{ml})$ and $n$-butanol $(1.5 \mathrm{ml})$ were then added, mixed, allowed to stand $15 \mathrm{~min}$, and then centrifuged at 2,000 $\times g$ for $10 \mathrm{~min}$. An $0.5-\mathrm{ml}$ aliquot of the butanol phase was removed, evaporated under nitrogen, redissolved in chromatographic solvent, and $40 \mu \mathrm{l}$ were placed on a silica gel plate and developed in a chloroform-methanol-acetic acid-water $(100 / 60 / 16 / 8, \mathrm{v} / \mathrm{v} / \mathrm{v} /$ v) system. The lecithin spot was identified by using an appropriate standard and iodine vapor, removed, and counted in a Beckman CMP-100 room temperature liquid scintillation system [34] (4 g 2,5-diphenyloxazole/100 ml toluene).

Ninety percent of the radioactivity on the silica plate appeared in the lecithin fraction. The assays were carried out in duplicate, and the duplicates agreed within $2-8 \%$. Blanks routinely gave $1 \%$ or less of the activity found in the standard assay.

\section{Results}

The synthesis of ${ }^{14} \mathrm{C}$-lecithin was linearly dependent upon protein concentration (Fig. 1). The reaction was linear for the first $15-30 \mathrm{~min}$, but plateaued at $30-4.5$ min (Fig. 2). Both the initial reaction rate and the amount of radioactive lecithin produced in a $45-\mathrm{min}$ incubation were reliable markers of activity when various tissue sources were used (Fig. 2).

Maximal lecithin synthesis was attained at CDP-choline concentrations greater than $0.20 \mathrm{mmol}$. The Michaelis constant $\left(K_{m}\right)$, calculated from a classical Lineweaver-Burk plot (Fig. 3), was $0.0143 \mathrm{mmol}$. The $\mathrm{pH}$ optimum for enzyme activity was 7.5-8.0 (Fig. 4).

The effects of several factors on phosphorylcholine glyceride transferase activity are shown in Table $\mathrm{I}$. $\mathrm{Mg}$ was a requirement for activity but Ca at $5.3 \mathrm{~mm}$ inhibited enzyme activity. The concentration of Triton X100 used in the standlard assay $(0.01 \%)$ inhibited enzyme activity only $10 \%$. A 10$)^{4}$ variation in dipalmitin

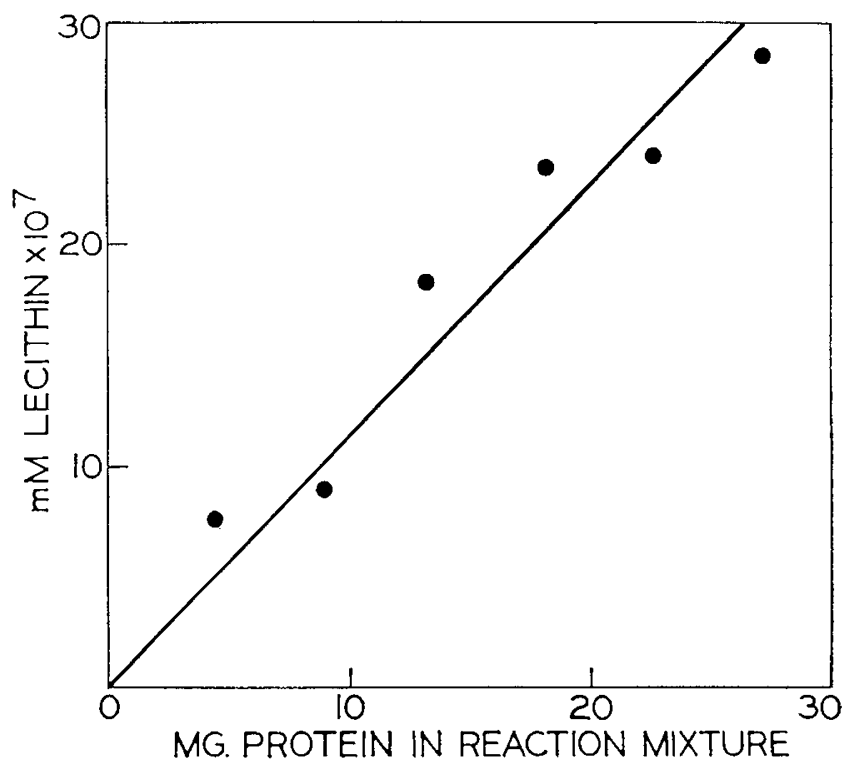

Fig. I. Effect of protein concentration on enzyme activity. The reaction mixture is described in the text. Varying amounts of homogenate were added and the activity and protein content of each determined. 


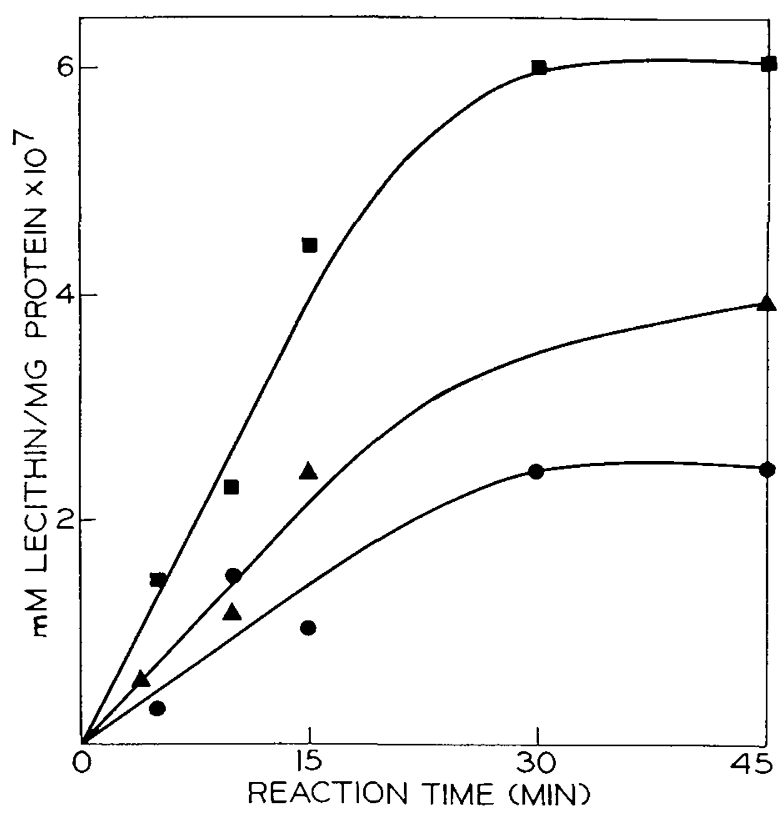

Fig. 2. Effect of time of incubation on initial reaction rate and product synthesis. Assay is as described in the text. The reaction was carried out for various times with lung samples from different patients.

, $B V, 26$ weeks gestation;

$\boldsymbol{A}, C R, 30$ weeks gestation; $-B L, 40$ weeks gestation).

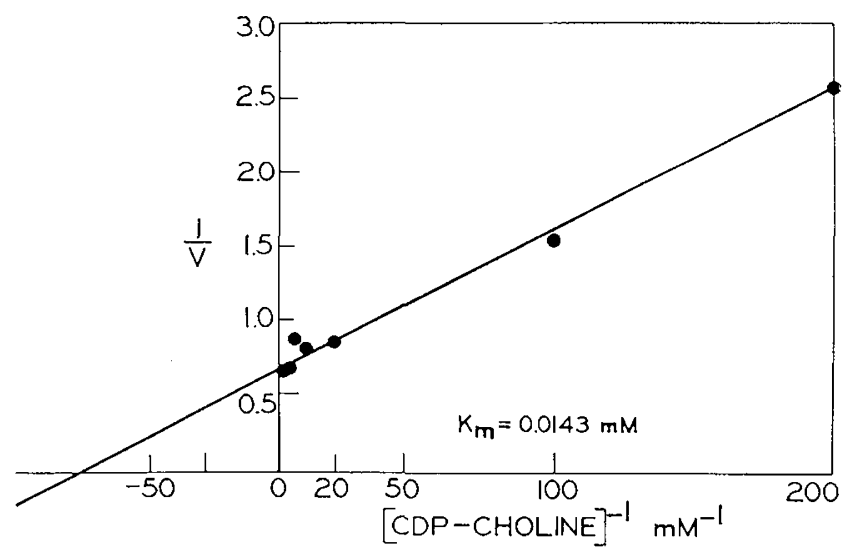

Fig. 3. Lineweaver-Burk reciprocal plot of the effect of cytidine diphosphorylcholine ( $C D P$-choline) concentration on enzyme activity. The CDP-choline in the reaction was varied as indicated, otherwise assay conditions were standard as described in Materials and Methods. $1 / V=\left[\mathrm{mm}\right.$ lecithin $\times 10^{7} / \mathrm{mg}$ protein $/ 45-\mathrm{min}$ incubation $]^{-1}$.

concentration did not raise activity over that of the crude homogenate alone. The enzyme was more active at temperatures of $35-39^{\circ}$ than $22^{\circ}$ or $55^{\circ}$ and whole homogenate was $20-50$ times as active as the supernatant derived by two different tissue homogenizing methods (Table I). No consistent effect of oxygen could be demonstrated. Enzyme activity was the same whether the gaseous phase over agitated reaction vessels was room air, $100 \%$ oxygen, or $100 \%$ nitrogen, in the presence or absence of cysteine.

The activities of phosphorylcholine glyceride transferase of the lung and liver of several patients are shown in Table II. In general, there is higher activity in the lung tissue from premature infants $(<32$ weeks gestation), with the highest values found in two very immature fetuses (20 weeks gestation). The difference in activity between the premature infants $\left(3.53 \times 10^{-7}\right.$ $\mathrm{mm}$ lecithin $/ \mathrm{mg}$ protein) and infants of longer gestation periods $\left(1.76 \times 10^{-7} \mathrm{~mm}\right.$ lecithin $/ \mathrm{mg}$ protein $)$ is statistically significant at the $95 \%$ confidence limit. Liver was slightly more active than lung, but the differences were not statistically significant at the $95 \%$ confidence limit. The apparent difference in liver enzyme activity between the same two gestational groups $\left(4.38 \pm 1.75 \times 10^{-7} \mathrm{~mm}\right.$ lecithin $/ \mathrm{mg}$ protein vs $2.94 \pm$ $1.24 \times 10^{-\tau} \mathrm{mm}$ lecithin $/ \mathrm{mg}$ protein) also was not statistically significant.

\section{Discussion}

Phosphorylcholine glyceride transferase activity in human newborn lung has been noted previously [13], but optimum conditions for enzyme activity were not

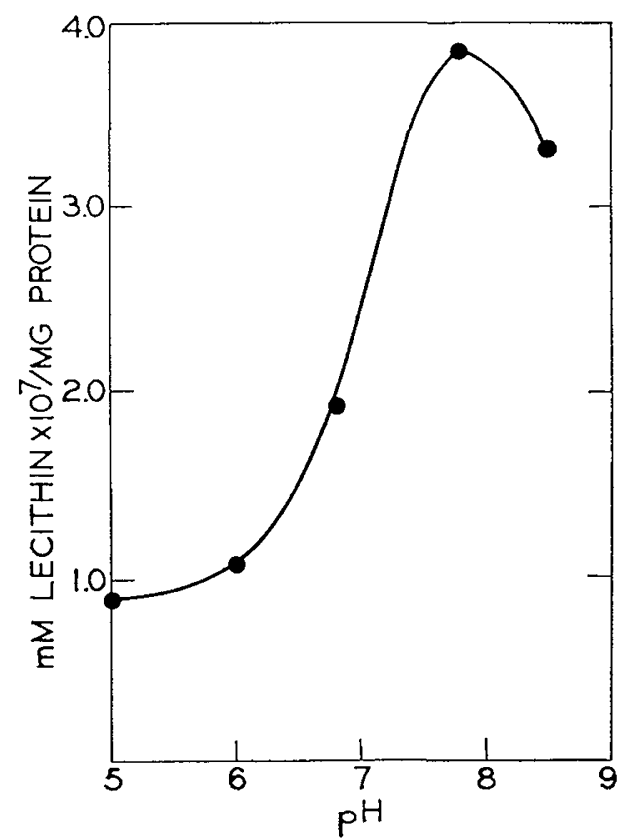

Fig. 4. Effect of $\mathrm{pH}$ on enzyme activity. The homogenates and substrates were prepared in phosphate buffer of varying $\mathrm{pH}$, and then the reaction was carried out as described in the text. The $\mathrm{pH}$ values are those of the entire reaction mixture. 
Table I. Effect of various reaction conditions on phosphoryl choline glyceride transferase activity

\begin{tabular}{|c|c|}
\hline Reaction conditions & Activity, $\%$ \\
\hline Complete $^{1}$ & 100 \\
\hline$-\mathrm{MgCl}_{2}$ & 0 \\
\hline$+\mathrm{MgCl}_{2},+\mathrm{CaCl}_{2}(5.3 \mathrm{~mm})$ & 15 \\
\hline \multicolumn{2}{|l|}{ Dipalmitin } \\
\hline 0 & 100 \\
\hline $0.0001 \mathrm{~mm}$ & 95 \\
\hline $0.001 \mathrm{~mm}$ & 101 \\
\hline $0.01 \mathrm{~mm}$ & 103 \\
\hline $1.0 \mathrm{~mm}$ & 97 \\
\hline \multicolumn{2}{|l|}{ Temperature } \\
\hline $0^{\circ}$ & 6 \\
\hline $22^{\circ}$ & 50 \\
\hline $35^{\circ}$ & 100 \\
\hline $37^{\circ}$ & 100 \\
\hline $55^{\circ}$ & 45 \\
\hline Whole homogenate, Teflon pestle & 100 \\
\hline Supernatant, Teflon pestle & 5 \\
\hline Whole homogenate, Virtis & 100 \\
\hline Supernatant, Virtis & 2 \\
\hline - Triton ${ }^{2}$ & 100 \\
\hline+ Triton, $0.01 \%(\mathrm{v} / \mathrm{v})$ & 90 \\
\hline+ Triton, $0.01 \%$ & 35 \\
\hline
\end{tabular}

${ }^{1}$ Complete reaction mixture as described in Materials and Methods.

${ }^{2}$ The control for the Triton experiments was a reaction mixture containing no dipalmitin.

Table II. Phosphorylcholine glyccride transferase in human newborn lung and liver

\begin{tabular}{|c|c|c|c|c|}
\hline \multirow{2}{*}{$\begin{array}{l}\text { Number } \\
\text { of } \\
\text { patients }\end{array}$} & \multirow{2}{*}{$\begin{array}{c}\text { Gestational } \\
\text { age, } \\
\text { wk }\end{array}$} & \multirow{2}{*}{$\begin{array}{c}\text { Average } \\
\text { birth } \\
\text { wt, g }\end{array}$} & \multicolumn{2}{|c|}{ Activity, m.s lecithin $\times 10^{7} / \mathrm{mg}$ protein } \\
\hline & & & Lung & Liver \\
\hline $11^{2}$ & $20-31$ & 810 & $3.53 \pm 1.23^{3}$ & $4.38 \pm 1.75$ \\
\hline 7 & $32-40$ & 2,501 & $1.6 \pm 0.75^{3}$ & $2.94 \pm 1.24$ \\
\hline
\end{tabular}

I Assay carried out under maximal conditions as described in the text. Results include \pm 95 percentile limits.

${ }^{2}$ Includes four fetuses of 20 weeks gestation received from operative procedures.

${ }^{3} P<0.05$.

determined and no other characterization of the enzyme was attempted. Characterization of the enzymes that synthesize pulmonary lecithin is necessary for a complete understanding of the relation between surfactant biosynthesis and respiratory distress syndrome. Phosphorylcholine glyceride transferase, the enzyme that transfers phosphorylcholine from cytidine diphosphate choline to $\mathrm{D}-\alpha, \beta$-diglyceride to form phosphati- dyl choline (lecithin), is of special interest. Depending on the availability of CDP-choline or diglyceride, phosphorylcholine glyceride transferase may serve as a regulator for lecithin biosynthesis [29]. In addition, of several enzymes studied in two lung lecithin biosynthetic pathways, only phosphorylcholine glyceride transferase activity was induced by corticosteroid administration to fetal rabbits [12].

The enzyme assay described is reliable. Activity is dependent upon time and protein concentration (Figs. 1 and 2). Optimal activity is attained by assaying near $\mathrm{pH} 7.5$ and $35-37^{\circ}$ in the presence of $0.5 \mathrm{~mm}$ CDP-choline and $\mathrm{MgCl}_{2}$. Duplicate determinations agreed well and assay blanks in the absence of the tissue homogenate enzyme preparation contained insignificant amounts of isotope in the lecithin fraction. The initial reaction rate and total product synthesis at $30-45 \mathrm{~min}$ vary with the tissue sample (Fig. 2).

The CDP-choline pathway for lecithin biosynthesis is active in several animal tissues $[2,5,16,17,21,27$, $28]$, some insects $[9,11,25]$, and a few microorganisms [26]. Some properties of phosphorylcholine glyceride transferase from human lung are similar to those in other tissues. The pH optimum of 7.5-8.0 of the human lung enzyme is near, but slightly towards the neutral side of the $\mathrm{pH}$ optima of 8-8.5 found in brain [17], muscle [21], and liver [28] of various animal species. $\mathrm{Mg}$ or $\mathrm{Mn}$ is required for activity in several systems studied thus far $[17,21,26,28]$, and $\mathrm{Mg}$ is required for phosphorylcholine glyceride transferase activity in lungs of human neonates, even when a whole homogenate preparation is used as the source of the enzyme. Temperature optima have been reported as $38^{\circ}$ in brain [17], $45^{\circ}$ in liver [28], and $37^{\circ}$ (in this laboratory) in human lung. Nonionic detergents are potent inhibitors of the enzyme from other sources [17, $26,28]$. Triton X-100, at the $0.01 \%$ level used in the standard assay, inhibited the human lung enzyme only $10 \%$. Calcium inhibition of the enzyme from other tissues is reported $[17,21,26,28]$. Calcium also inhibited the human lung enzyme, but at the high concentrations used $(5.3 \mathrm{~mm})$, it is difficult to say that this was a direct or an indirect action, such as particulate precipitation.

Some differences in phosphorylcholine glyceride transferase from human lung and other sources are of interest. The $K_{m}$ for CDP-choline is reported as 1.3-2.2 $\times 10^{-4} \mathrm{M}[17,28,29]$ in other systems and $1.4 \times 10^{-5}$ $\mathrm{M}$ in human lung. Assay conditions, the type of enzyme preparation (whole homogenate, microsomal, 
etc.), or the source of the enzyme may account for this apparent difference. This enzyme is reported to be microsomal in rabbit lung [14], rat brain [17], chicken and rat liver [28, 29], and is particulate in certain larvae [25]. Whole homogenate was required for activity in the present system, and this contained enough endogenous diglyceride so that added dipalmitin had no effect on product formation (Table 1 ). With other more purified enzyme preparations [19, 21], exogenous diglyceride was required for maximal activity.

Artom [2] has shown that lung phosphorylcholine glyceride transferase reached full activity near the time of birth in the rat. In rabbit, however, the incorporation of $\operatorname{CDP}\left(1,2-{ }^{14} \mathrm{C}\right)$-choline into lecithin was maximal in the preterm rabbit fetal lung and decreased towards term [14]. The enzyme has been noted in immature human fetal lung, but with very low activity [13]. The studies shown here suggest that human premature lung has a higher phosphorylcholine glyceride transferase activity than human lung tissue from later gestations (Table II). A similar finding was noted for choline kinase [30]. Further interpretation at this point is difficult because of the heterogeneous population and the nonspecific method of choosing the site of tissue removal in this study. The patients varied not only in gestational age, but also in age at death, type of disease, and therapy. Studies relating these factors and enzyme activity are continuing.

\section{Summary}

Phosphorylcholine glyceride transferase activity in human newborn lung was assayed. The enzyme preparation was made by homogenizing lung tissue (removed at autopsy and frozen until used) in phosphate buffer, and assayed by determining the amount of CDP-choline- ${ }^{14} \mathrm{C}$ incorporated into radioactive lecithin in the presence of magnesium and dipalmitin. Product synthesis was dependent upon protein concentration, time of incubation, temperature, cofactors, and $\mathrm{pH}$. Activity was higher in lungs of immature-premature infants than in lungs of later gestations, and liver tended to have greater enzyme activity at all gestations.

\section{References and Notes}

I. Adams, F. H., Fujiwara, T., Emmanounidifs, G., ann Scudner, A.: Surface properties and lipids from lungs of infants with hyaline membrane disease. J. Pediat., 66: 357 (1965).

2. Akrom, C.: Enzymes for the synthesis of lecithins from choline in tissues of developing rats. Fed. Proc., 27: 457 (1968).
3. Avery, M. E., AND Mead, J.: Surface propertics in relation to atelectasis and hyaline membrane disease. Amer. J. Dis. Child., $97: 517(1959)$.

4. Baldwin, J., and Connatzer, W. E.: Liver lipids during development. Lipids, 3: 361 (1968).

5. BJøknstad, P., AND Brfmir, J.: In vito studies on pathways for the biosynthesis of lecithin in the rat. J. Lipid Res., $7: 38$ (1966).

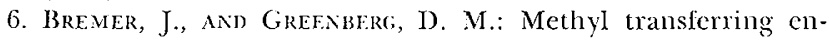
zyme system of microsomes in the biosynthesis of lecithin (phosphatidylcholine). Biochim. Biophys. Acta, 46: 205 (1961).

7. Brown, E. S.: Isolation and assay of dipalmityl lecithin in lung extracts. Amer. J. Physiol., 207: 402 (1964).

8. Brumley, G. W., Honson, W. A., And Avery, M. E.: Lung phospholopids and surface tension correlations in infants with and without hyaline membrane clisease and in adults. Pediatrics, f0: 13 (1967).

9. ChojNicki, T., AND Korzi bski, S.: On the specificity of cytidine cocnzymes in the incorporation of $O$-phosphorylcholine into phospholipids by tissue homogenates of various animal species. Acta Biochim. Pol, 10: 455 (1963).

10. Chu, J., Clements, J. A., Cotton, E. K., Klaus, M. H., Sweet, A. Y., Тномаs, M. A., ANd 'Tooley, W. H.: The pulmonary hypoperfusion syndrome. Pediatrics, 35: 733 (1965).

11. Cronfe, H. D., Newburcir, R. W., and Mezer, C.: The larval fat body of Sarcophaga bullata as a system for studying phospholipid synthesis. J. Insect Physiol., 12: 619 (1966).

12. Farrei.t, P. M., and Zachman, R. D.: Cortiscosteroid mediated induction of phosphorylcholine glyceride transferase and lecithin biosynthesis in the fetal rabbit lung. Science, 179: 297 (1973).

13. (xluck, L., Kulovich, M. V., Eimfinan, A. I., Cordero, I., and KhAZIN, A. F.: Biochemical development of surface activity in mammalian lung. IV. Pulmonary lecithin synthesis in the human fetus and newborn and etiology of the respiratory distress syndrome. Pediat. Res., 6: 81 (1972).

14. Gluck, I., SRibney, M., ANd Kul.ovich, M. J.: The biochemical development of suface activity in mammalian lung. II. The biosynthesis of phospholipids in the lung of the developing rabbit fetus and newbom. Pediat. Res., 1 : 247 (1967).

15. Grumwald, P., Johnson, R. P., Husted, R. F., and Ci.ements, J. A.: Correlation of mechanical properties of infant lungs with surface activity of extracts. Proc. Soc. Exp. Biol. Med., 109: 369 (1962).

16. KENNidY, E. P., AND Weiss, S. B3.: The function of cytidinc coenzymes in the biosynthesis of phospholipids. J. Biol. Chem., 2.22: $193(1956)$.

17. MCCaman, R. E., AND CoOK, K.: Intermediary metabolism of phospholipids in brain tissue. III. Phosphocholine glyceride transferase. J. Biol. Chem., 2t1: 3390 (1966).

18. Morgan, T. E.: Isolation and characterization of lipid $N$ methyltransferase from dog lung. Biochim. Biophys. Acta, 178 : $21(1969)$.

19. MUdi), J. B., VAN Golnf, I. M. ('., AND VAN DERen, L. L. M.: Ctilization of molecular species of diglycerides in the synthesis of lecithin. Biochim. Biophys. Acta, 176: 547 (1969).

20. Pattle, R. E., Ciatreaux, A. E., Daviys, P. A., and Camiron, A. J.: Inability to form a lung lining film as a cause of the respiratory distress syndrome in the newborn. Lancet, $i i: 469$ (1962). 
21. Pranington, R. J., AND Worsfold, M.: Biosynthesis of lecithin by skeletal muscle. Biochim. Biophys. Acta, 176: 774 (1969).

22. Scarpelli, E. M., Clutario, B. C., and Tayloor, F. A.: Preliminary identification of the lung surfactant system. J. Appl. Physiol., 23: 880 (1967).

23. Scarpfeld, E. M.: The Surfactant System of the I.ung, Chapt. 4, p. 53. (Lea and Febiger, Philadelphia, 1968).

24. Scarpeiti, E. M.: 'The Surfactant System of the Lung, Chapt. 8, p. I77. (I.ca and Febiger, Philadelphia, 1968).

25. SHellify, R. M., ANI) Hod(son, E.: Biosynthesis of phosphatidylcholine in the fat body of Phormin regina larvae. J. Insect Physiol., 16: 131 (1970).

26. Smith, J. D., AND Law, J. H.: Phosphatidylcholine biosynthesis in Tetrahymena pyriformis. Biochim. Biophys. Acta, 202: 141 (1970).

27. Weinhold, P. A.: Biosynthesis of phosphatidylcholine during prenatal development of the rat lung. J. Lipid Res., 9: 262 (1968).

28. Wrass, S. B., Surmh, S. W., AND KenNFdy, E. P.: The enzymatic formation of lecithin from cytidine diphosphate choline and 1)-1,2-diglyceride. J. Biol. Chem., 231:53 (1958).

29. Young, D. L., AND Lrinen, F.: Enzymatic regulation of 3-sn- phosphatidylcholine and triacyglycerol synthesis in states of altered lipid metabolism. J. Biol. Chem., 24t: 377 (1969).

30. Zachman, R. D.: The enzymes of lecithin biosynthesis in human newborn lungs. I. Choline kinase. Biol. Neonate, 19: 211 (1971).

31. Zachman, R. D.: The enzymes of lecithin biosynthesis in human newborn lungs. If. Methionine-activating enzyme and phosphatidyl methyltransferase. Biol. Neonate, 20: 448 (1972).

32. Waltham, Mass.

39. St. Louis, Mo.

34. Beckman Instruments, Inc., Palo Alto, Calif.

35. Presented in part at the 42nd Annual Meeting of the Society for Pediatric Research, Washington, D.C., May 1972.

36. This research was supported in part by grants from The John A. Hartford Foundation and the Public Health Scrvice (HD $0,5837)$.

37. The previous technical assistance of Ms. Edelle Kinsinger is acknowledged.

38. Recuests for reprints should be addressed to: Richard D. Zachanan, Ph.I)., M.D., Neonatal Biochemistry Research Laboratories, St. Mary's Hospital Medical Center, 720 South Brooks St., Madison, Wis. 53715 (USA).

39. Accepted for publication February 28, 1973. 